Forthcoming at Sociology of Religion

\title{
Keep America Christian (and White): Christian Nationalism, Fear of Ethnoracial Outsiders, and Intention to Vote for Donald Trump in the 2020 Presidential Election
}

\author{
Joseph O. Baker \\ East Tennessee State University \\ Samuel L. Perry \\ University of Oklahoma \\ Andrew L. Whitehead \\ Clemson University
}

\begin{abstract}
Some of the strongest predictors of voting for Donald Trump in the 2016 presidential election were Christian nationalism and antipathy toward Muslims and immigrants. We examine the interrelated influence of these three factors on Americans' intentions to vote for Trump in 2020. Consistent with previous research, Christian nationalism and Islamophobia remained strong and significant predictors of intention to vote for Trump; however, the effect of xenophobia was stronger. Further, xenophobia and Islamophobia significantly and substantially mediated the effects of Christian nationalism. Consequently, though Christian nationalism remains theoretically and empirically distinct as a cultural framework, its influence on intending to vote for Trump in 2020 is intimately connected to fears about ethnoracial outsiders. In the penultimate year before Trump's reelection campaign, the strongest predictors of supporting Trump, in order of magnitude, were: political party, xenophobia, identifying as African American (negative), political ideology, Christian nationalism, and Islamophobia.
\end{abstract}

Key words: Donald Trump, 2020 presidential election, Christian nationalism, xenophobia, Islamophobia, partisanship, fear, public opinion

Correspondence: Direct all correspondence to Joseph O. Baker, email: bakerjo@etsu.edu; address: East Tennessee State University, Box 70644, East Tennessee State University, Johnson City, TN 37614. Author order is alphabetical because each author contributed equally to this work.

This is the author's manuscript of the article published in final edited form as:

Baker, J. O., Perry, S. L., \& Whitehead, A. L. (2020). Keep America Christian (and White): Christian Nationalism, Fear of Ethnoracial Outsiders, and Intention to Vote for Donald Trump in the 2020 Presidential Election. Sociology of Religion, 81(3), 272-293. https://doi.org/10.1093/socrel/sraa015 


\section{INTRODUCTION}

Following the surprising outcome of the 2016 presidential election, numerous studies sought to uncover the key factors behind Donald Trump's victory, as well as on ongoing support (or disdain) for Trump and his administration. This research highlights a variety of demographic, social, and ideological explanations for Trump support including, among other: political polarization (Oberhauser, Krier, and Kusow 2019; Sides, Tesler, and Vavreck 2018), economic dissatisfaction (Schafner, MacWilliams, and Nteta 2018), sexism (Bracic, Israel-Trummel, and Shortle 2019; Schaffner et al. 2018), racism (Luttig, Frederico, and Lavine 2017; Major, Blodorn, and Blascovich 2018; Reny, Collingwood, Valenzuela 2019; Schaffner et al. 2018), cultural insecurity (Mutz 2018; Cox, Lienesch, and Jones 2017), religious affiliation (Margolis 2018), fear of religious minorities (especially Muslims) (Guth 2019; Tucker at al. 2019;

Whitehead, Perry, and Baker 2018), and xenophobia (Edgell 2017; Guth 2019; Reny et al. 2019).

Included in this list is Christian nationalism, which had a strong association not only with voting for Trump, but also with a variety of political wedge issues commonly used by Trump to energize his base (Whitehead and Perry 2020). Leading up to the 2016 election, Trump successfully tapped into many Americans' desires to see Christianity privileged in the public sphere, an effort to return America to its mythic past as an overtly "Christian nation.” Indeed, over and above common measures of personal religiosity or partisanship, Americans who strongly embraced Christian nationalism were much more likely to vote for Trump (Whitehead et al. 2018; see also Braunstein 2018).

Three years into Trump's term in office and heading toward the 2020 presidential election, it is imperative to re-examine ongoing support for Trump to determine whether previous explanations still hold true, or whether significant shifts have taken place in Trump's 
support during his time in office. In the current study, we extend prior analyses by assessing how ideological predictors of supporting Trump are becoming increasingly intertwined. Recent research on Christian nationalism, for example, shows it is one of the strongest predictors of Americans holding antipathy toward immigrants (McDaniel et al. 2011; Sherkat and Lehman 2018) and Muslims (Shortle and Gaddie 2015)—each powerful predictors of support for Trump in their own right. We theorize that the Trump administration's consistent messaging around Christian nationalist themes, denigration of immigrants and religious minorities (especially Muslims), and the blatant polarization of political rhetoric has resulted in Trump being less dependent on any one of these strategies alone. Instead, these issues are deeply interconnected and mutually reinforcing by virtue of their shared fears about cultural, and especially, ethnoracial "outsiders." We use data from a nationally-representative sample of American adults surveyed in the latter half of 2019 to examine the interrelated influence of Christian nationalism, xenophobia, and Islamophobia on intentions to vote for Donald Trump in the 2020 election.

\section{EMPIRICAL AND THEORETICAL BACKGROUND}

\section{Causes of Trump Voting and Support}

Because Donald Trump's victory in 2016 was surprising and his margin of victory was relatively thin across a handful of counties in several swing states, the search for explanations about who voted for Trump and continues to support him has been extensive. One significant finding is that many non-college educated white Americans residing in the rust belt (or those states that proved to be consequential to the electoral college outcome) did in fact swing from supporting Obama in 2012 to Trump in 2016 (Farley 2019; Morgan and Lee 2018). While some speculated that economic dissatisfaction drove the Trump vote, research does not support this. 
For instance, one study showed that rurality and social identity—but not economic distresspushed many to vote for Trump (Oberhauser et al. 2019), while another found hostile sexism (especially) and denial of racial inequality to be much more important predictors than economic dissatisfaction (Schaffner et al. 2018). Using panel data from 2012 to 2016, Mutz (2018: E4330) found that changes in financial well-being did not predict support for Trump; rather, feelings of cultural anxiety, or threats to "white Americans' sense of dominant group status" fueled this constituency's vote for Trump (see also PRRI 2017).

Moreover, as these tests of economic versus cultural and racial explanations suggest, race and racism consistently predict not only who voted for Trump, but also his sources of ongoing support. Experimental research, for example, shows that white Trump supporters are more hostile toward proposed housing policies if they feel such policies will help African Americans rather than whites (Luttig et al. 2017). Similarly, fears of whites becoming a minority by 2042 caused experimental participants to increase their support for Trump and anti-immigrant policies (Major et al. 2018). Likewise, Americans who hold negative views of African Americans are more likely to support and vote for Trump (Green and McElwee 2017; Sides et al. 2018), as are those who deny that racism is an ongoing problem (Schaffner et al. 2018). As a rather obvious corollary of these findings, research shows that support for Trump is overwhelmingly located among white Americans. Exit polls from the 2016 election show that white women and men (especially) were, by a large margin, more likely to vote for Trump compared to other demographic groups (Pew 2018). Polls and research continue to show that white Americans remain by far the most positive about Trump and the job he is doing in office (Guth 2019). Vital to Trump's ongoing support are white Christians, especially white evangelical Protestants. In exit polls from 2016 and ongoing public opinion surveys, the vast majority of 
white evangelicals remain Trump supporters, suggesting a deepening connection between evangelical affiliation and partisan politics (Margolis 2018; Martí 2018). Indeed, there is a growing body of research pointing to the ongoing support of Donald Trump as a "natural outcome" for white Christianity, and especially white evangelicalism, given its long history of intertwining race and partisanship with religion (Edgell 2017; Fea 2018; Jones 2016; Martí 2020; Tisby 2019). Central to this history is a particular cultural framework borne of white Christian America that provides ideological scaffolding for certain ethnoracial assumptions about American identity: Christian nationalism.

\section{Christian Nationalism, Xenophobia, and Islamophobia}

Christian nationalism is a cultural schema advocating the synthesis of American civic life with a particularist (almost ethnic) form of Christianity (Gorski 2017). As a collection of narratives, traditions, myths, value systems, and symbols, Christian nationalism expresses the belief that America is distinctively "Christian," and that this should be reflected in its public policies, sacred symbols, and national identity. Though employing overtly religious language, inextricably embedded in this cultural framework are also assumptions about race, nativism, and a hierarchical ordering of society that benefits those who have historically held the levers of power - white, straight, native-born, Protestant men (Whitehead and Perry 2020). Forms of “identitarian Christianism” (Brubaker 2017; see also Gorski 2017) have been emerging across the globe in response to perceived demographic and cultural threats, and the comparatively high religiosity and evangelical vocabulary of the American public allows Christian nationalism in the

U.S. to disguise its covertly ethnic and authoritarian agenda within overtly religious language.

A variety of studies demonstrate that Christian nationalism is a powerful cultural framework that is influential beyond traditional religious boundaries (Braunstein and Taylor 
2017; Delehanty, Edgell, and Stewart 2019), and is significantly associated with a host of consequential outcomes, including: minorities' access to material resources (Edgell et al. forthcoming), support for the death penalty and other authoritarian methods of social control (Davis 2018), relative political tolerance for racists (Davis and Perry 2020), opposition to interracial families (Perry and Whitehead 2015a, 2015b), denial of police brutality toward blacks (Perry, Whitehead, and Davis 2019), negative attitudes toward immigrants (McDaniel et al. 2011; Sherkat and Lehman 2018) and religious minorities (Dahab and Omori 2019; Shortle and Gaddie 2015; Stewart, Edgell, and Delehanty 2018), opposition to gun control (Whitehead, Schnabel, and Perry 2018), support for gender traditionalism (Whitehead and Perry 2019), and negative attitudes toward sexual minorities (Whitehead and Perry 2015).

Most important for the current study, however, is that in the 2016 presidential election, the degree to which Americans embraced Christian nationalism significantly and strongly predicted their vote for Trump, even after accounting for various other explanations like economic anxiety, sexism, racism, xenophobia, and Islamophobia (Whitehead et al. 2018). Interestingly, however, Whitehead et al. (2018) also found that Christian nationalism had significant indirect effects on the probability of voting for Trump through its strong associations with both xenophobia and Islamophobia. Likewise, a recent study of Trump support highlighted that white evangelicals, a group that overwhelmingly embraces Christian nationalism, "share with Trump a multitude of attitudes, including his hostility toward immigrants, his Islamophobia, his racism, and nativism" (Guth 2019: 32). ${ }^{1}$

\footnotetext{
${ }^{1}$ So closely related are these factors-Christian nationalism, xenophobia, and Islamophobia-that some scholars approach them under the umbrella of single constructs, such as "authoritarian populism" (Norris
} 
Along with appeals to the nation's Christian heritage, fear of and antipathy toward immigrants generally and Muslims specifically has been a central component of Trump's electoral campaign and governance. In effect, Trump capitalized on and consolidated a long-term trend toward the increasing political polarization around issues of immigration and fear of (Muslim) terrorists (Bader et al. 2020). As recently as the 1990s, anti-immigrant voters were relatively evenly distributed across parties, but over time these voters have become increasingly concentrated in the Republican Party (Abrajano and Hajnal 2015; Hajnal and Rivera 2014). Consequently, political polarization around immigration has also increased (Sides et al. 2018).

Closely related to public views about race and immigration are attitudes toward Muslims, which became increasingly negative after 9/11 and a subsequent backlash occurring in negative media coverage of Islam (Bail 2012, 2014), followed by a corresponding negative turn in public opinion (Peek 2011). Such anti-Muslim views are amplified to the extent that people perceive Muslims as a cultural threat (Gerteis, Hartmann, and Edgell 2019). Empirical research finds a close connection between negative views of immigrants and Muslims in Western countries, such that people with xenophobic attitudes also tend to have Islamophobic attitudes (Kalkan, Layman, and Uslaner 2009; Strabac and Listhaug 2008). Trump effectively played to both xenophobia and Islamophobia during his 2016 campaign, with his central features of the southern border wall and "tough on terrorism" dog-whistle rhetoric. Both were strong ideological predictors of voting for Trump in 2016 (Guth 2019; Reny et al. 2019; Tucker et al. 2019; Whitehead et al. 2018). The connections between Christian nationalism, xenophobia, and Islamophobia were overtly emphasized during Trump's 2016 campaign, with consistent efforts at drawing strong boundaries

and Inglehart 2019) or "ethno-traditional nationalism" (Kaufmann 2019). Our findings affirm the interrelatedness of these factors, but also show the extent to which they are distinct. 
around nationality and religiosity to designate who qualifies as a "real American."

The move toward partisanship around xenophobia and Islamophobia in the U.S. reflects trends taking place around the world. For example, this connection between Christian identity and fear of dark-skinned immigrants and Muslims also characterizes the "European populist moment" that brought about Brexit and the rise of Boris Johnson (Brubaker 2017). Given Trump's policies concerning non-Christian minority groups, asylum seekers, and immigrants, we expect that alongside Christian nationalism, Islamophobia and xenophobia remain powerfully important for explaining continued support for Trump. Further, we anticipate that these factors may be even more strongly related in the 2020 election compared to 2016.

\section{METHODS}

\section{Data}

To address these research questions, we analyze data from the 2019 administration of the Chapman University Survey of American Fears (CSAF). The CSAF has been collected annually since 2014, with the goal of documenting a wide variety of social, political, and psychological fears among the American public (see Bader et al. 2020). The surveys were developed through the Earl Babbie Research Center at Chapman University by a team of sociologists and political scientists. The 2019 wave of the CSAF was collected by Social Science Research Solutions (SSRS) using their nationally-representative online Probability Panel of participants. ${ }^{2}$ The data

\footnotetext{
${ }^{2}$ Participants in the SSRS Probability Panel are recruited randomly from the SSRS Omnibus survey, which is completed weekly using a dual-frame, random digit dialing sampling frame. In 2019, the response rate for the typical Omnibus survey was 5\%, although the majority of Probability Panel participants were recruited in previous years when response rates were slightly higher $(\approx 7-8 \%)$.
} 
were collected from August $7^{\text {th }}$ until August $26^{\text {th }}, 2019$, with a total of 1,219 valid respondents. The timing of the survey gives us a useful data point, as the effects of the rhetoric and actions of the Trump administration have had three years to suffuse into American culture. It is also far enough removed from the 2020 election season that there was not yet a clear opponent to Trump.

Panelists were sent an initial email invitation to complete the survey and received a $\$ 7.00$ incentive for participating. Five rounds of reminder emails were sent to potential respondents from underrepresented demographic categories throughout the survey period. In all, 2,438 potential respondents from the Probability Panel were asked to participate, with 1,281 completing the survey, and a final $\mathrm{N}$ of 1,219 after removing 62 respondents who failed quality control checks embedded within the survey. Overall, the cooperation rate for the survey was $53 \%$. The data were weighted to match demographic benchmarks for the population of the U.S. based on gender, age, education, race/ethnicity, region, and civic engagement. The weight was used for all analyses presented. The total margin of error for the sample for estimating population parameters of the American public was $\pm 3.8 \%$.

\section{Measures}

\section{Dependent Variable}

Our dependent variable asks respondents who they would vote for in the 2020 presidential election if it were held at the time of the survey (August of 2019). The question asked: "If the presidential election were held today, for whom would you vote?" The answer choices were Donald Trump, the Democratic nominee, a third-party candidate, and would not vote. We coded respondents who said they would not vote $(n=143)$ as missing, since we are interested in vote choice rather than voting vs. not voting. We then recoded the other responses so that intending to vote for Trump $=1$ and intending to vote for a Democrat or third-party 
candidate $=0 .{ }^{3}$ Overall, $37 \%$ of respondents intending to vote in the 2020 election reported that they would vote for Trump, closely approximating Trump's approval rating at the time, which was estimated by Gallup to be $39 \%$ during August $15^{\text {th }}-30^{\text {th }}, 2019 .^{4}$

\section{Independent Variables}

\section{Christian Nationalism}

To measure Christian nationalism, we used an index combining responses to five separate questions on the survey, which were based on Whitehead at al.'s (2018) previous study of Christian nationalism and voting for Trump in 2016. These questions asked for respondents' levels of agreement with the following statements: "The federal government should declare the United States a Christian nation"; "The federal government should advocate Christian values"; "The federal government should enforce strict separation of church and state"; "The federal government should allow the display of religious symbols in public spaces"; and "The federal government should allow prayer in public schools." The five questions had Likert disagree/agree response options ranging from "strongly disagree" (1) to "strongly agree" (4). The question about the separation of church and state was reverse coded so that respondents who disagreed

\footnotetext{
${ }^{3}$ In supplemental analyses we ran a multinomial logistic model predicting voting for a Democrat or thirdparty candidate separately compared to voting for Trump (see Table A3). The effect of Christian nationalism was stronger for predicting Trump voting vs. voting for a Democrat compared to Trump voting vs. third-party voting, indicating a connection between Christian nationalism and partisan polarization. Latter-day Saint respondents were significantly more likely to report an intention to vote for a third-party candidate.

${ }^{4}$ Gallup's estimates of Trump's approval ratings over time are available at: https://news.gallup.com/poll/203198/presidential-approval-ratings-donald-trump.aspx.
} 
scored higher. The index had good internal reliability, with a Cronbach's $\alpha=.861$ (see Table 1).

\section{Xenophobia}

Another focal independent variable used for analysis was an index of attitudes toward immigrants. This measure combined responses to seven questions about immigrants, using Likert response options ranging from "strongly disagree" (1) to "strongly agree" (4). The specific indicators used were: "Immigrants are more likely to commit crime than U.S. citizens"; "Recent immigrants are more reluctant to assimilate than previous immigrants"; "Immigrants are a drain on the economy"; "Immigrants bring diseases to the United States"; "Police should be allowed to raid businesses and homes in order to find undocumented workers"; "Deportation is a good solution to immigration issues"; and "Creating a 'pathway to citizenship' will encourage illegal immigration.” These items were developed by the CSAF research team based on previous measures of xenophobia in conjunction with content analyses of news stories about immigrants

in the U.S. used to identify key issues and discourse (Baker, Cañarte, and Day 2018). The battery attempts to capture multiple dimensions of perceived threat shown to be important cross-cultural components of xenophobia —including economic, medical, cultural, and criminal—tailored to samples from the U.S. The index had high internal reliability, with a Cronbach's $\alpha=.918$.

\section{Islamophobia}

Closely related to xenophobia is the concept of Islamophobia. Whitehead et al. (2018) found that Islamophobia was a strong predictor of voting for Trump in 2016, and further that a significant and substantial proportion of the covariance between Christian nationalism and Trump voting was mediated through Islamophobia. Here we measure this concept with an index created from five separate items that had response options on a Likert scale ranging from "strongly disagree" (1) to "strongly agree" (4). These asked for respondents' levels of agreement 
with the following statements: "I think it is OK for Muslims to receive extra screening at the airport"; "Muslims are more likely to engage in terrorist activity than non-Muslims"; "Muslim values are at odds with American values and way of life"; "I would have a problem with my child marrying a Muslim"; and "I would be comfortable with having a mosque (a place of worship for Muslims) in my neighborhood." The last item was reverse coded so that higher scores indicate opposition to having Muslim neighbors. Similar xenophobia, the Islamophobia measure is intended to capture multiple dimensions of perceived threat, particularly criminal and cultural. The index had high internal reliability, with a Cronbach's $\alpha=.901$.

To examine the extent to which Christian nationalism, xenophobia, and Islamophobia were distinct or overlapping, we conducted a factor analysis with all items from each of the indices using maximum likelihood extraction and an oblique (Promax) rotation that allows the factors to be inter-correlated (Table 1). Two things are apparent. First, it is defensible to use these three indices independently, as the specific items all loaded most strongly on their respective factors. Second, however, it is also clear that these three concepts are highly interrelated, particularly xenophobia and Islamophobia, which have a very high inter-correlation $(\mathrm{r}=$ .755). In short, these factors are distinct, but also largely measure a broader concept tapping into general fears about ethnoracial outsiders. Christian nationalism is also strongly correlated with both xenophobia $(r=.602)$ and Islamophobia $(r=.595)$. Here we keep these measures distinct for consonance with previous research and our interest in examining the extent to which specific forms of ethnoracial fears are mediating the effects of Christian nationalism on voting patterns. At the same time, these results clearly show how closely aligned Christian nationalism, xenophobia, and Islamophobia are with one another among the American public. 


\section{Control Variables}

In addition to our focal independent variables, we included controls for sociodemographic, political, and religious characteristics known to be related to our independent variables and voting patterns in the U.S. In addition, we included an interesting control available from the 2019 CSAF that asked whether respondents were fearful of whites becoming a minority in the U.S. Given that this fear has been shown to be related to Trump support in prior research (Major et al. 2018) and has been proposed as a possible driver of the political ascendance of Christian nationalism (e.g., Jones 2016), we included this measure in our initial models as a baseline control, so that we could see the extent to which the addition of the Christian nationalism measure accounted for any variance between fear about a white minority and voting for Trump. This question asked: "How afraid are you of the following events? Whites no longer being the majority in the U.S." Answer choices ranged from "not afraid" (1) to "very afraid" (4). Bivariate analysis with Trump voting shows that the differences on the outcome for this variable were between respondents who answered "not afraid" and all other responses. Those who reported being "slightly afraid," "afraid," and "very afraid" of whites becoming a minority reported an intention to vote for Trump at similar proportions $(69 \%, 69 \%$, and 74\%, respectively; compared to $28 \%$ of respondents who were not afraid of whites becoming a minority). As such, we recoded this measure as a binary variable between those who were not afraid of a white minority future for the U.S. (78\% of respondents), and all other responses.

For sociodemographic controls, we included dummy variables for gender $(\operatorname{men}=1)$, employment (full-time employee $=1$ ), and marital status (married $=1$ ). We included ordinal measures of annual income level (ranging from less than $\$ 20,000$ per year [1] to $\$ 150,000$ per year or more [9]) and education in attainment categories (ranging from less than high school [1] 
to post-graduate or professional degree [8]). Because financial hardship has been proposed as a potential factor explaining support for Trump among the American public (Edgell 2017), we included a measure of fears about one's financial situation with responses to three items. These asked: "How afraid are you of the following:" "Not having enough money for the future"; "Being unemployed"; and "High medical bills." Responses ranged from "not at all afraid" (1) to "very afraid" (4). The items were combined into a financial fears index (Cronbach's $\alpha=.776$ ).

Region of the country was measured with a series of dummy variables for the Northeast, Midwest, and West, with the South serving as the reference category in multivariate models. Similarly, racial and ethnic self-identification was measured with a series of dummy variables for black, Hispanic, Asian, and mixed or other races/ethnicities, with whites as the excluded category in multivariate models. We also controlled for the age, measured in years.

For political characteristics, we included controls for political ideology and party identification. For political ideology, we used a question that asked: "How would you describe yourself politically?" Answer choices ranged from "extremely conservative" (1) to "extremely liberal" (7), with "moderate" as the middle category (4). For political party identification, we used a question that asked: "Do you think of yourself as a Republican, Democrat, or independent?" Answer choices ranged from “strong Republican" (1) to "strong Democrat” (7), with independents as the middle category (4).

For religious characteristics, we include controls for religious affiliation and frequency of religious service attendance. We categorized respondents as conservative Protestant (reference category), moderate or liberal Protestant, Catholic, Jewish, Mormon, other religions, or no religion. The 2019 CSAF does not have information on respondents' specific Protestant denominations, and only has general designations such as "Baptist" or "Presbyterian." In order to 
split Protestants into conservative and moderate categories we used responses to a second question about views of the Bible. Protestant respondents who identified as biblical literalists were coded as conservative, and those who selected a different answer the Bible views question were coded as moderate or liberal Protestants. ${ }^{5}$ Religious service attendance was measured from "never" (1) to "several times a week" (9).

\section{Analytic Strategy}

Table A1 in the online appendix shows descriptive information for all variables used for analyses in the study. To provide descriptive information on the relationship between Christian nationalism, Islamophobia, and xenophobia, respectively, in relation to intention to vote for Trump, we present contingency tables that bin our independent variables of interest into four categories, displaying the percentage of respondents who said they would vote for Trump in each bin, along with $\chi^{2}$ and $\gamma$ statistics to assess the significance and relative strength of these relationships. Next, we provide descriptive information about the percentage of Americans who hold Christian nationalist, Islamophobic, and xenophobic views, as well as the extent to which people holding these ideologies overlap.

We then use binary logistic regression models to examine patterns in intending to vote for Trump. We used a three-stage approach to the models. The first model includes all sociodemographic, religious, and political controls, as well as the measure assessing fears about whites becoming a minority in the U.S. The second model adds the Christian nationalism measure. Changes in the fear of a white minority measure between Model 1 and Model 2 provide an indication of whether fears about changes to diversity and demographics are at least partially

\footnotetext{
${ }^{5}$ We also ran supplemental models with the full Bible views question included as a separate variable. Greater biblical orthodoxy was a significant predictor of Trump voting $(\mathrm{p}<.05)$.
} 
driving the relationship between Christian nationalism and support for Trump. The third model adds the xenophobia and Islamophobia measures to the model. Changes in the effects of Christian nationalism between Models 2 and 3 provide an initial indication of whether the relationship between Christian nationalism and Trump support is mediated through fears about immigrants and Muslims.

For all models we report unstandardized coefficients for the independent variables, and for Model 3 we also calculated and report fully standardized coefficients, which are analogous to beta coefficients in OLS regression models (see Menard 2011). This provides an assessment of the relative magnitude of the relationship between each of the independent variables and support for Trump. We also used the results from Model 3 to calculate and display the predicted probabilities of voting for Trump across different scores on the Christian nationalism, xenophobia, and Islamophobia measures for respondents, with all control variables set to their respective means.

To provide a more rigorous assessment of the mediation of the effects of Christian nationalism on Trump support through fears about immigrants and Muslims, we present results from PROCESS multiple mediation models (see Hayes 2017; Preacher and Hayes 2004, 2008). PROCESS is a form of path modeling based on regression that allows for the assessment of multiple mediators simultaneously. We used PROCESS models with 1000 bootstrapped samples to estimate the indirect effects of Christian nationalism (on this procedure, see MacKinnon et al. 2002). This is also the analytic method used by Whitehead et al. (2018) to examine mediators of Christian nationalism, allowing us to compare the current results to those found for Trump voting in the 2016 presidential election. 


\section{RESULTS}

Table 2 shows the bivariate results for the percentage of respondents reporting that they would vote for Trump by levels of Christian nationalism, Islamophobia, and xenophobia. Each of the independent variables was condensed into four categories (low, mid-low, mid-high, and high). ${ }^{6}$ Strong, positive relationships between each of these variables and Trump voting are readily apparent. Notably, for all three measures, of respondents who scored at the maximum on the respective indices, $100 \%$ reported an intention to vote for Trump. The strongest relationship is found for the xenophobia index, which had a remarkably high $\gamma$ coefficient (.923).

\section{<Insert Table 2 About Here>}

Next, we looked at descriptive information for how many respondents held substantively high levels of Christian nationalist, Islamophobic, and xenophobic attitudes (see Table A2 in the online appendix). To do this we set substantive criteria, such that respondents needed to affirm three of the five items on the Christian nationalism or Islamophobia indices to be considered as holding the respective ideology, and that respondents had to affirm five of the seven antiimmigrant items to be considered as "xenophobic." ${ }^{7}$ Using these designations, $42 \%$ of respondents did not meet the threshold for any of the three indices; however, this leaves nearly $60 \%$ of Americans who hold high levels of at least one of these three ideologies. Forty-six percent of respondents scored above the threshold for Christian nationalism, as did $36 \%$ for

\footnotetext{
${ }^{6}$ For Christian nationalism and Islamophobia these categories had four scores each $(5-8,9-12,13-16$, and 17-20). For xenophobia, the middle categories have six scores each (12-17 and 18-23) and the low and high categories have five scores each (7-11 and 24-28).

${ }^{7}$ To do this we dichotomized each indicator for the respective indices into disagree/agree, and then created count scores for each index.
} 
Islamophobia, and $25 \%$ for xenophobia.

Looking at holding these ideologies in isolation or conjunction, $16.6 \%$ of respondents could be considered Christian nationalists without displaying high substantive levels of prejudice toward immigrants or Muslims. Fourteen percent of respondents were Christian nationalists accompanied by either Islamophobia $(9.5 \%)$ or xenophobia $(4.5 \%)$. Fully $15.3 \%$ of respondents scored above the substantive thresholds on all three ideologies. In sum: while Christian nationalism can, and sometimes is, held without Islamophobia or xenophobia in conjunction, it is more likely to be held in concert with fears about ethnoracial outsiders than without.

Table 3 shows the results of the binary logistic regression models predicting an intention to vote for Trump over other candidates. In Model 1, the variable about fearing whites no longer being the majority in the U.S. is marginally significant $(b=.548 ; p=.06) .{ }^{8}$ Liberal political views $(b=-.784 ; p<.001)$ and Democratic partisan identification $(b=-1.232 ; p<.001)$, as well as self-identification as black $(b=-2.422 ; \mathrm{p}<.001)$ or Hispanic $(\mathrm{b}=-1.359 ; \mathrm{p}<.001)$ are all strongly and significantly related to lower odds of Trump voting. Compared to African Americans, white Americans have eleven times higher odds of intending to vote for Trump, a

\footnotetext{
${ }^{8}$ In supplemental models that removed the controls for political views and partisanship, fear about whites becoming a racial minority was the second strongest predictor in the model, after the differences between white and black Americans. Before accounting for political identification, Americans who fear whites losing majority status were 3.8 times more likely to vote for Trump than those who did not have this fear. In supplemental analyses, we examined the indirect effects of fears about whites being a minority through political views, partisan identification, Christian nationalism, xenophobia, and Islamophobia using a PROCESS mediation model. Although fear of whites being a minority did not a have a significant direct effect on Trump voting, it had significant indirect effects through all of these variables (see Figure A1).
} 
reflection of the fact that only $3.3 \%$ of black respondents reported they would vote for Trump. Similarly, but less drastically, white Americans have nearly four times greater odds of Trump voting compared to Hispanic Americans. Older Americans, $(b=.016 ; p<.05)$ were also significantly more likely to say they intended to vote for Trump.

Notably, all religious traditions are significantly less likely to say they would vote for Trump compared to conservative Protestants in Model 1. The odds of Conservative Protestants supporting Trump are more than two and half times greater than the odds of moderate and liberal Protestants. Similarly, conservative Protestants have 4.4 times greater odds of Trump support than Catholics, 5.2 times higher odds than Jews, 2.5 times higher odds than those in the "other religions" category, and 6.3 times higher odds than religious nones. The largest substantive difference between conservative Protestants and another religious tradition in Model 1 was with Mormon respondents $(b=-3.068 ; \mathrm{p}<.001)$.

Model 2 adds the Christian nationalism measure to the model, which was strongly and positively related to Trump voting $(b=.274 ; \mathrm{p}<.001)$. Notably the size of the race fear variable is attenuated by $47 \%$ with the inclusion of the Christian nationalism variable, indicating a strong connection between fears about a white minority and Christian nationalism. ${ }^{9}$ Model 3 adds the measures for Islamophobia $(b=.124 ; p<.05)$ and xenophobia $(b=.210 ; p<.001)$, both of which are significantly and positively related to intending to vote for Trump. After controlling for Christian nationalism, xenophobia, and Islamophobia, the differences between conservative Protestants and all other religious traditions aside from Latter-day Saints $(b=-2.262 ; p<.01)$

\footnotetext{
${ }^{9}$ Among those scoring at the three lowest possible outcomes on the Christian nationalism measure, only $3.7 \%$ reported any fear about whites being a minority. Among those scoring at the three highest possible outcomes on the Christian nationalism measure, half (50.4\%) reported fears about future racial diversity.
} 
and the nonreligious $(b=-1.112 ; \mathrm{p}<.05)$ become statistically non-significant. The differences between conservative Protestants and other religious traditions in terms of Trump support primarily reflect differential levels of Christian nationalism, xenophobia, and Islamophobia.

Looking at the fully standardized coefficients calculated for Model 3, the strongest predictors of voting for Trump (or not), in order of magnitude, are: partisan identity $(\beta=-.332$ ), xenophobia $(\beta=.229)$, being African American $(\beta=-.160)$, political ideology $(\beta=-.131)$, Christian nationalism $(\beta=.125)$, Islamophobia $(\beta=.100)$, and being Hispanic $(\beta=-.099)$. In sum, partisanship, fears about ethnoracial outsiders, ethnic or racial self-identification, and Christian nationalism are the factors that matter most for supporting Trump heading into the 2020 presidential election. ${ }^{10}$ This is an extremely efficient model, explaining over 82 percent of the variance in intention to vote for Trump.

\section{<Insert Table 3 About Here>}

Figure 1 shows the predicted probabilities of voting for Trump across scores on the Christian nationalism, xenophobia, and Islamophobia indices, with all other controls set to their respective means. At the lowest levels of all three measures (-1.5 standard deviations below their means), the probability of voting for Trump is under .10. The likelihood of intending to vote for Trump rises steadily as Christian nationalism and Islamophobia increase, to .39 and .30 at the

\footnotetext{
${ }^{10}$ In supplemental models we also examined whether racial or ethnic self-identification moderates the effect of Christian nationalism on Trump support. Christian nationalism actually had a significantly stronger effect for African Americans for supporting Trump compared to whites (see Table A4). Of the five African American respondents who said they intended to vote for Trump, all of them were above the mean on Christian nationalism. In contrast, Christian nationalism had a significant negative effect on Trump support among Hispanic respondents (see Figure A2).
} 
highest levels, respectively. The stronger effects of xenophobia are evident here, with the predicated probability of intending to vote for Trump at the highest levels of xenophobia being .72. Clearly views of immigration are the central cultural component for understanding support for or opposition to Donald Trump going into the 2020 election.

\section{<Insert Figure 1 About Here>}

Figure 2 shows the results of the PROCESS multiple mediation model assessing how much of the effect of Christian nationalism on Trump voting is mediated through Islamophobia and xenophobia. Here we can see the significant direct effect of Christian nationalism on Trump voting remains. There are also significant indirect effects through both Islamophobia and xenophobia, shown with $95 \%$ confidence intervals for the size of the indirect effects. About half (49\%) of the total effect of Christian nationalism on intention to vote for Trump was mediated through concerns about ethnoracial outsiders in the form of immigrants and Muslims. ${ }^{11}$ Notably these indirect effects are larger than those found by Whitehead et al. (2018) examining the same issues with the same analytic technique, where $31 \%$ of the overall effect of Christian nationalism on Trump voting was mediated through xenophobia, Islamophobia, and racial prejudice. ${ }^{12}$

\footnotetext{
${ }^{11}$ In a supplemental PROCESS model, we looked the mediation of Christian nationalism through a combined measure of xenophobia and Islamophobia. In this model, xenophobia and Islamophobia mediated $52 \%$ of the overall total effect of Christian nationalism on intention to vote for Trump. ${ }^{12}$ To more rigorously test whether the connection between Christian nationalism to xenophobia and Islamophobia had gotten stronger in relation to Trump support, we created a merged dataset from the 2017 Baylor Religion Survey and 2019 CSAF. We included only comparable variables from both datasets, then ran a moderated mediation PROCESS model looking for significant differences in
} 


\section{<Insert Figure 2 About Here>}

Overall, our current findings demonstrate that Christian nationalism continues to have a strong and significant independent effect on Trump's support well into the president's first term. At the same time, Christian nationalism is also strongly tethered to antipathy toward people perceived as ethnoracial outsiders, and this is also an integral aspect of explaining its continued connection to supporting Trump on the eve of his reelection campaign.

\section{DISCUSSION}

Whitehead et al.'s (2018) study stressed the centrality of Christian nationalism on voting for Trump in the 2016 election. Our findings affirm the continued importance of Christian nationalism, but with some important changes. Notably, we find that, beyond partisanship, xenophobia is the most important key to understanding continued support for Trump just prior to his 2020 reelection campaign. Further, in contrast to Whitehead et al.'s (2018) finding about voting in 2016, in the 2019 CSAF data, xenophobia and Islamophobia explain a larger amount of the covariance between Christian nationalism and Trump voting. Some of this difference likely reflects the CSAF having a more comprehensive measure of antipathy toward immigrants; however some of this change may also be due to an increasing cultural and ideological affinity between Christian nationalism and xenophobia in the Trump era.

Taken in concert with prior research, these findings also foreshadow serious implications for various ethnoracial and religious minority groups in the United States, especially those at intersectional axes of discrimination. As Edgell and colleagues (forthcoming) show, the symbolic boundaries that cultural frameworks like Christian nationalism create correspond to

mediation across samples (see Figure A3). There was significantly more mediation of Christian nationalism through xenophobia in 2019. 
social boundaries that limit access to important material resources. ${ }^{13}$ The first three years of the Trump administration clearly demonstrate that non-native, non-Christian asylum seekers, refugees, or immigrants are viewed as undeserving of resources and support from the federal government. As our findings show, these policies are indeed often compatible with the desires of Americans who embrace Christian nationalism. Christian nationalists are and will remain solidly behind Trump when he moves to limit immigration, stokes fears around border crossings, or bans people from majority-Muslim countries.

The interrelated nature of Christian nationalism, xenophobia, and Islamophobia in predicting intentions to re-elect Trump also suggests that the United States is coming into greater alignment with contemporary populist developments around the globe. Researchers have increasingly recognized the highly-ethnicized (and concurrently xenophobic and often Islamophobic) character of religious nationalism in other contexts, including Europe, India, and Brazil (Brubaker 2017; Kaufmann 2019; Heller 2019). Christian nationalism in the U.S. has too often been construed in purely religious terms, as a conflict between cultural worldviews or narratives of religious heritage. This evidence of increased overlap between Christian nationalism and fear of ethnoracial "outsiders" underscores the degree to which religion is inherently raced (Yukich and Edgell 2020). Though we empirically affirm that Christian nationalism is not interchangeable with xenophobia or Islamophobia, the three are clearly symbiotic and their interdependence merits further attention and analysis.

While indications to vote for Trump are noteworthy, data gathered throughout the 2020 election season and soon after will be necessary to compare the patterns we have identified here

\footnotetext{
${ }^{13}$ A potentially important factor we were unable to measure is the perceived threat of secular Americans and how this relates to Christian nationalism and Trump support (see Edgell et al. forthcoming).
} 
with actual voting patterns. Cultural frameworks like Christian nationalism also evolve and adapt, even in relatively short amounts of time (Whitehead and Scheitle 2018), so continuing to explore the sociopolitical dynamics of Christian nationalism with survey data is critical. Further, qualitative studies are vitally important, as the relationship between Christian nationalism and Americans' support for Trump is multi-faceted and can be obscured when using quantitative analyses alone (Whitehead and Perry 2020).

Going into the 2020 U.S. presidential election, the relative magnitude of different social, religious, and ideological characteristics in relation to voting patterns remains to be seen. Although we can only speculate about what kind of changes will occur to the tight connections between xenophobia, partisanship, and Christian nationalism thereafter, a safe bet would be the continuation of existing trends toward increased polarization. If that is indeed the case, then American politics will be mired in disputes over these Christian nationalism and fears about ethnoracial "outsiders" for at least the next generation.

\section{REFERENCES}

Abrajano, Marisa and Zoltan L. Hajnal. 2015. White Backlash: Immigration, Race, and American Politics. Princeton: Princeton University Press.

Bail, Christopher. 2012. "The Fringe Effect: Civil Society Organizations and the Evolution of Media Discourse about Islam since the September 11th Attacks.” American Sociological Review 77(6): 855-879.

Bail, Christopher. 2014. Terrified: How Anti-Muslim Fringe Organizations Became Mainstream. Princeton: Princeton University Press.

Bader, Christopher D., Joseph O. Baker, L. Edward Day, and Ann Gordon. 2020. Fear Itself: 
The Causes and Consequences of Fear in America. New York: NYU Press.

Baker, Joseph O., David Cañarte, and L. Edward Day. 2018. "Race, Xenophobia, and

Punitiveness Among the American Public." Sociological Quarterly 59(3): 363-383.

Bracic, Ana, Mackenzie Israel-Trummel, and Allyson F. Shortle. 2019. "Is Sexism for White People? Gender Stereotypes, Race, and the 2016 Presidential Election.” Political Behavior 41: 281-307

Braunstein, Ruth. 2017. "Muslims as Outsiders, Enemies, and Others: The 2016 Presidential Election and the Politics of Religious Exclusion." American Journal of Cultural Sociology 5: 355-372.

Braunsten, Ruth. 2018. “A (More) Perfect Union? Religion, Politics, and Competing Stories of America." Sociology of Religion 79(2):172-195.

Braunstein, Ruth and Malaena Taylor. 2017. "Is the Tea Party a "Religious" Movement? Religiosity in the Tea Party versus the Religious Right.” Sociology of Religion 78: 33-59.

Brubaker, Rogers. 2017. "Between Nationalism and Civilizationism: the European Populist Moment in Comparative Perspective.” Ethnic and Racial Studies 40(8):1191-1226.

Cox, Daniel, Rachel Lienesch, and Robert P. Jones. 2017. "Beyond Economics: Fears of Cultural Displacement Pushed the White Working Class to Trump." PRRI.

Dahab, Ramsey and Marisa Omori. 2019. "Homegrown Foreigners: How Christian Nationalism and Nativist Attitudes Impact Muslim Civil Liberties.” Racial and Ethnic Studies 42(10): $1727-1746$.

Davis, Joshua. 2018. "Enforcing Christian Nationalism: Examining the Link Between Group I Identity and Punitive Attitudes in the United States." Journal for the Scientific Study of Religion 57(2): 300-317. 
Delehanty, Jack, Penny Edgell, and Evan Stewart. 2018. "Christian America? Secularized Evangelical Discourse and the Boundaries of National Belonging.” Social Forces 97(3): $1283-1306$.

Edgell, Penny. 2017. “An Agenda for Research on American Religion in Light of the 2016 Election." Sociology of Religion 78(1): 1-8.

Edgell, Penny, Evan Stewart, Sarah C. Billups, and Ryan Larson. Forthcoming. "The Stakes of Symbolic Boundaries.” Sociological Quarterly https://doi.org/10.1080/00380253.2019.1625736.

Farley, John E. 2019. "Five Decisive States: Examining How and Why Donald Trump Won the 2016 Election." Sociological Quarterly 60(3): 337-353.

Fea, John. 2018. Believe Me: The Evangelical Road to Donald Trump. Grand Rapids, MI: Eerdmans.

Gerteis, Joseph, Douglas Hartmann, and Penny Edgell. Forthcoming. "Racial, Religious, and Civic Dimensions of Anti-Muslim Sentiment in America." Social Problems https://doi.org/10.1093/socpro/spz039.

Green, Jon and Sean McElwee. 2019. "The Differential Effects of Economic Conditions and Racial Attitudes in the Election of Donald Trump." Perspectives on Politics 17(2): 358379.

Guth, James L. 2019. “Are White Evangelicals Populists? The View from the 2016 American National Election Study." The Review of Faith \& International Affairs 17(3): 20-35. Hajnal, Zoltan and Michael Rivera. 2014. "Immigration, Latinos, and White Partisan Politics: The New Democratic Defection.” American Journal of Political Science 58: 773-789. Hayes, Andrew F. 2017. Introduction to Mediation, Moderation, and Conditional Process 
Analysis: A Regression-Based Approach, second edition. New York: Guilford Press.

Heller, Patrick. 2019. "Divergent Trajectories of Democratic Deepening: Comparing Brazil, India, and South Africa.” Theory and Society 48:351-382.

Jones, Robert P. 2016. The End of White Christian America. New York, NY: Simon \& Schuster.

Kalkan, Kerem Ozan, Geoffrey Layman, and Eric Uslaner. 2009. “'Bands of Others'? Attitudes toward Muslims in Contemporary American Society.” The Journal of Politics 71: 1-16.

Kaufmann, Eric. 2019. Whiteshift: Populism, Immigration, and the Future of White Majorities. New York: Abrams.

Luttig, Matthew D., Christopher M. Federico, and Howard Lavine. 2017. "Supporters and Opponents of Donald Trump Respond Differently to Racial Cues: An Experimental Analysis." Research \& Politics 4(4): 1-8.

McDaniel, Eric L., Irfan Nooruddin, Allyson Faith Shortle. 2011. "Divine Boundaries: How Religion Shapes Citizens' Attitudes toward Immigrants.” American Politics Research 39: 205-233.

MacKinnon, David P., Chondra M. Lockwood, Jeanne M. Hoffman, Stephen G. West, and Virgil Sheets. 2002. "A Comparison of Methods to Test Mediation and Other Intervening Variable Effects." Psychological Methods 7: 83-104.

Major, Brenda, Alison Blodorn, Gregory Major Blascovich. 2018. "The Threat of Increasing Diversity: Why Many White Americans Support Trump in the 2016 Presidential Election." Group Processes \& Intergroup Relations 21(6): 931-940.

Margolis, Michele F. 2018. From Politics to the Pews: How Partisanship and the Political Environment Shape Religious Identity. Chicago: Chicago University Press.

Martí, Gerardo. 2018. "The Unexpected Orthodoxy of Donald J. Trump: White Evangelical 
Support for the 45th President of the United States." Sociology of Religion 80(1): 1-8. Martí, Gerardo. 2020. American Blindspot: Race, Class, Religion, and the Trump Presidency. Lanham, MD: Rowan \& Littlefield.

Menard, Scott. 2011. "Standards for Standardized Logistic Regression Coefficients." Social Forces 89(4): 1409-28.

Morgan, Stephen L. and Jiwon Lee. 2018. "Trump Voters and the White Working Class.” Sociological Science 5(10): 234-45.

Mutz, Diana C. 2018. “Status Threat, Not Economic Hardship, Explains the 2016 Presidential Vote." Proceedings of the National Academy of Sciences 115(19) E4330-E4339.

Norris, Pippa, and Ronald Inglehart. 2019. Cultural Backlash: Trump, Brexit, and Authoritarian Populism. Cambridge, UK: Cambridge University Press.

Oberhauser, Ann M., Daniel Krier, and Abdi M. Kusow. 2019. "Political Moderation and Polarization in the Heartland: Economics, Rurality, and Social Identity in the 2016 U.S. Presidential Election.” Sociological Quarterly 60(2): 224-244.

Peek, Lori. 2011. Behind the Backlash: Muslim Americans After 9/11. Philadelphia: Temple University Press.

Perry, Samuel L., and Andrew L. Whitehead. 2015a. "Christian Nationalism and White Racial Boundaries: Examining Whites’ Opposition to Interracial Marriage.” Ethnic and Racial Studies 38: 1671-1689.

Perry, Samuel L., and Andrew L. Whitehead. 2015b. "Christian Nationalism, Racial Separatism, and Family Formation: Attitudes toward Transracial Adoption as a Test Case." Race and Social Problems 7: 123-134.

Perry, Samuel L., Andrew L. Whitehead, and Joshua Davis. 2019. “God's Country in Black and 
Blue: How Christian Nationalism Shapes Americans' Views about Police (Mis)treatment of Blacks.” Sociology of Race and Ethnicity 5(1): 130-146.

Pew Research Center. 2018. 'For Most Trump Voters, 'Very Warm’ Feelings for Him Have Endured." https://www.people-press.org/2018/08/09/an-examination-of-the-2016electorate-based-on-validated-voters/.

Preacher, Kristopher J., and Andrew F. Hayes. 2004. "SPSS and SAS Procedures for Estimating Indirect Effects in Simple Mediation Models.” Behavior Research Methods, Instruments, and Computers 36: 717-731.

Preacher, Kristopher J., and Andrew F. Hayes. 2008. “Asymptotic and Resampling Strategies for Assessing and Comparing Indirect Effects in Multiple Mediator Models.” Behavior Research Methods 40: 879-891.

Reny, Tyler T., Loren Collingwood, and Ali A. Valenzuela. 2019. "Vote Switching in the 2016 Election: How Racial and Immigration Attitudes, Not Economics, Explain Shifts in White Voting." Public Opinion Quarterly 83 (1): 91-113.

Schaffner, Brian F., Matthew Macwilliams, and Tatishe Nteta. 2018. "Understanding White Polarization in the 2016 Vote for President: The Sobering Role of Racism and Sexism.” Public Opinion Quarterly 133(1): 9-34.

Sherkat, Darren and Derek Lehman. 2018. "Bad Samaritans: Religion and Anti-Immigrant and Anti-Muslim Sentiment in the United States.” Social Science Quarterly 99: 1791-1804.

Shortle, Allyson F., and Ronald Keith Gaddie. 2015. "Religious Nationalism and Perceptions of Muslims and Islam.” Politics and Religion 8: 435-57.

Sides, John, Michael Tesler, and Lynn Vavreck. 2018. Identity Crisis: The 2016 Presidential Campaign and the Battle for the Meaning of America. Princeton: Princeton Press. 
Stewart, Evan, Penny Edgell, and Jack Delehanty. 2018. “The Politics of Religious Prejudice and Tolerance for Cultural Others.” Sociological Quarterly 59(1): 17-39.

Strabac, Zan and Ola Listhaug. 2008. "Anti-Muslim Prejudice in Europe: A Multilevel Analysis of Survey Data from 30 Countries.” Social Science Research 37: 268-86.

Tisby, Jemar. 2019. The Color of Compromise. Grand Rapids, MI: Zondervan.

Tucker, Patrick D., Michelle Torres, Betsy Sinclair, and Steven S. Smith. 2019. "Pathways to Trump: Republican Voters in 2016.” Electoral Studies 61: 102035.

Whitehead, Andrew L., and Samuel L. Perry. 2015. “A More Perfect Union? Christian Nationalism and Support for Same-Sex Unions." Sociological Perspectives 58: 422-440.

Whitehead, Andrew L., and Samuel L. Perry. 2019. “Is a 'Christian America' a More Patriarchal America? Religion, Politics, and Traditionalist Gender Ideology." The Canadian Review of Sociology 56(2): 151-177.

Whitehead, Andrew L. and Samuel L. Perry. 2020. Taking America Backfor God: Christian Nationalism in the United States. New York: Oxford University Press.

Whitehead, Andrew L., Samuel L. Perry, and Joseph O. Baker. 2018. "Make American Christian Again: Christian Nationalism and Voting for Donald Trump in 2016 Presidential Election." Sociology of Religion 79(2): 147-171.

Whitehead, Andrew L., and Christopher P. Scheitle. 2017. "We the (Christian) People: Christianity and American Identity from 1996 to 2014.” Social Currents 5(2): 157-172. Whitehead, Andrew L., Landon Schnabel, and Samuel L. Perry. 2018. "Gun Control in the Crosshairs: Christian Nationalism and Opposition to Stricter Gun Laws.” Socius 4: 1-13. Yukich, Grace and Penny Edgell. 2020. Religion is Raced: Understanding American Religion in the Twenty-First Century. New York: New York University Press. 
TABLE 1. Factor Analysis of Christian Nationalism, Xenophobia, and Islamophobia Items

\begin{tabular}{|c|c|c|c|}
\hline Item & Factor 1 & Factor 2 & Factor 3 \\
\hline Gov. should declare U.S. Christian & .589 & .604 & .772 \\
\hline Gov. should advocate Christian values & .547 & .560 & .804 \\
\hline Gov. should separate church and state & -.374 & -.451 & -.549 \\
\hline Gov. should display of religious symbols & 458 & 369 & .738 \\
\hline Gov. should allow prayer in public schools & .464 & .424 & .829 \\
\hline Immigrants commit more crime & .825 & .665 & .566 \\
\hline Immigrants do not assimilate & 734 & .600 & 462 \\
\hline Immigrants are drain on economy & .839 & 645 & .557 \\
\hline Immigrants bring diseases & .846 & 654 & .555 \\
\hline Police should raid business and homes & .801 & .599 & 481 \\
\hline Deportation is solution to immigration & .853 & .672 & .564 \\
\hline Path to citizenship encourages immigration & .642 & .520 & .379 \\
\hline Muslims should receive extra screening & .697 & .856 & .534 \\
\hline Muslims are more likely to be terrorists & .646 & .858 & .463 \\
\hline Muslims hold anti-American values & 697 & .827 & .558 \\
\hline Would not want child to marry a Muslim & 617 & .769 & 469 \\
\hline Uncomfortable with mosque as neighbor & .598 & .746 & .506 \\
\hline \multicolumn{4}{|l|}{ Reliability statistics and inter-correlations } \\
\hline $\begin{array}{l}\text { Cronbach's } \alpha \text { or Pearson's r } \\
\text { for xenophobia index }\end{array}$ & $.918^{\alpha}$ & & \\
\hline $\begin{array}{l}\text { Cronbach's } \alpha \text { or Pearson's } r \\
\text { for Islamophobia index }\end{array}$ & $.755^{\mathrm{r}}$ & $.901^{\alpha}$ & \\
\hline $\begin{array}{l}\text { Cronbach's } \alpha \text { or Pearson's } r \\
\text { for Christian nationalism index }\end{array}$ & $.602^{\mathrm{r}}$ & $.595^{\mathrm{r}}$ & $.861^{\alpha}$ \\
\hline
\end{tabular}

Source: 2019 Chapman Survey of American Fear

Extraction: Maximum Likelihood

Rotation: Promax (oblique) with Kaiser normalization

Note: $\alpha$ : Cronbach's reliability coefficient for index; r: Pearson's correlation with index. 
TABLE 2. Percent Reporting They Will Vote for Trump by Levels of Christian Nationalism, Islamophobia, and Xenophobia (column percentages)

\begin{tabular}{lccc}
\hline $\begin{array}{l}\text { Level of } \\
\text { independent variable }\end{array}$ & $\begin{array}{c}\text { Christian } \\
\text { Nationalism }\end{array}$ & Islamophobia & Xenophobia \\
\hline Low & $3.6 \%$ & $4.2 \%$ & $3.0 \%$ \\
Mid-low & $25.8 \%$ & $28.9 \%$ & $23.2 \%$ \\
Mid-high & $56.0 \%$ & $68.8 \%$ & $78.2 \%$ \\
High & $79.7 \%$ & $90.3 \%$ & $97.6 \%$ \\
\hline$\chi^{2}$ & $294.679 * * *$ & $441.987 * * *$ & $555.643 * * *$ \\
$\gamma$ & .762 & .861 & .923 \\
\hline
\end{tabular}

Source: 2019 Chapman Survey of American Fears $* * * \mathrm{p}<.001$ 
TABLE 3. Binary Logistic Regression Models Predicting Voting for Trump

\begin{tabular}{|c|c|c|c|c|}
\hline Variables & Model 1 & Model 2 & Model 3 & $\boldsymbol{\beta}$ \\
\hline Christian nationalism & --- & $.274 * * *$ & $.170 * *$ & .125 \\
\hline \multicolumn{5}{|l|}{ Fears of "outsiders" } \\
\hline Xenophobia & --- & --- & $.210 * * *$ & .229 \\
\hline Islamophobia & --- & --- & $.124 *$ & .100 \\
\hline \multicolumn{5}{|l|}{ Fear of diversity } \\
\hline Race fear & $.548^{\dagger}$ & .292 & -.532 & -.042 \\
\hline \multicolumn{5}{|l|}{ Sociodemographics } \\
\hline Gender & .371 & $.646^{*}$ & $.482^{\dagger}$ & .045 \\
\hline Employed & .346 & .281 & .476 & .045 \\
\hline Income & .064 & .081 & .024 & .012 \\
\hline Financial fears & -.015 & .003 & -.004 & .002 \\
\hline Education & -.091 & -.016 & .040 & .013 \\
\hline Married & -.086 & -.231 & -.059 & -.006 \\
\hline Northeast $^{\mathrm{a}}$ & $-.581 *$ & $-.470^{\dagger}$ & $-.505^{\dagger}$ & -.037 \\
\hline Midwest $^{\mathrm{a}}$ & -.696 & -.634 & -.636 & -.048 \\
\hline West $^{\mathrm{a}}$ & -.126 & .123 & .275 & .022 \\
\hline Black $^{\text {b }}$ & $-2.422 * * *$ & $-2.862 * * *$ & $-2.657 * * *$ & -.160 \\
\hline Hispanic $^{\mathrm{b}}$ & $-1.359 * * *$ & $-1.467 * * *$ & $-1.475^{* * *}$ & -.099 \\
\hline Asian ${ }^{b}$ & $-1.386^{\dagger}$ & -.919 & -1.304 & -.048 \\
\hline Other or mixed race ${ }^{b}$ & .285 & .109 & .056 & .002 \\
\hline Age & $.016^{*}$ & $.016^{*}$ & .011 & .039 \\
\hline Metro & -.130 & -.132 & $-.183 *$ & -.052 \\
\hline \multicolumn{5}{|l|}{ Politics } \\
\hline Political views & $-.784 * * *$ & $-.588 * * *$ & $-.419 * *$ & -.131 \\
\hline Party identity & $-1.232 * * *$ & $-1.165^{* * *}$ & $-.971 * * *$ & -.332 \\
\hline Religion & & & & .000 \\
\hline Service attendance & -.038 & $-.113^{*}$ & -.075 & -.037 \\
\hline Mod/lib Protestant ${ }^{c}$ & $-.905^{*}$ & $-.929 *$ & -.662 & -.054 \\
\hline Catholic $^{c}$ & $-1.491 * * *$ & $-1.156^{*}$ & -.706 & -.055 \\
\hline Jewish $^{\mathrm{c}}$ & $-1.643^{\dagger}$ & -1.127 & -.775 & -.022 \\
\hline Mormon $^{\mathrm{c}}$ & $-3.068 * * *$ & $-2.935^{* * *}$ & $-2.262 * *$ & -.067 \\
\hline Other religions ${ }^{c}$ & $-.908 *$ & -.591 & -.375 & -.025 \\
\hline No religion $^{c}$ & $-1.836 * * *$ & $-1.211^{*}$ & $-1.112 *$ & -.097 \\
\hline \multicolumn{5}{|l|}{ Model stats } \\
\hline $\mathrm{N}$ & 1109 & 1108 & 1103 & \\
\hline Constant & 8.442 & 3.494 & -1.279 & \\
\hline-2 log likelihood & 503.335 & 470.31 & 411.795 & \\
\hline Nagelkerke $\mathrm{R}^{2}$ & .777 & .795 & .825 & \\
\hline
\end{tabular}

Source: 2019 Chapman Survey of American Fears $\dagger \mathrm{p}<.1 ; * \mathrm{p}<.05 ; * * \mathrm{p}<.01 ; * * * \mathrm{p}<.001$

a: South is reference; $b$ : White is reference; c: Conservative Protestant is reference 
FIGURE 1. Predicted Probability of Intending to Vote for Trump in 2020

by Levels of Christian Nationalism, Xenophobia, and Islamophobia

0.80

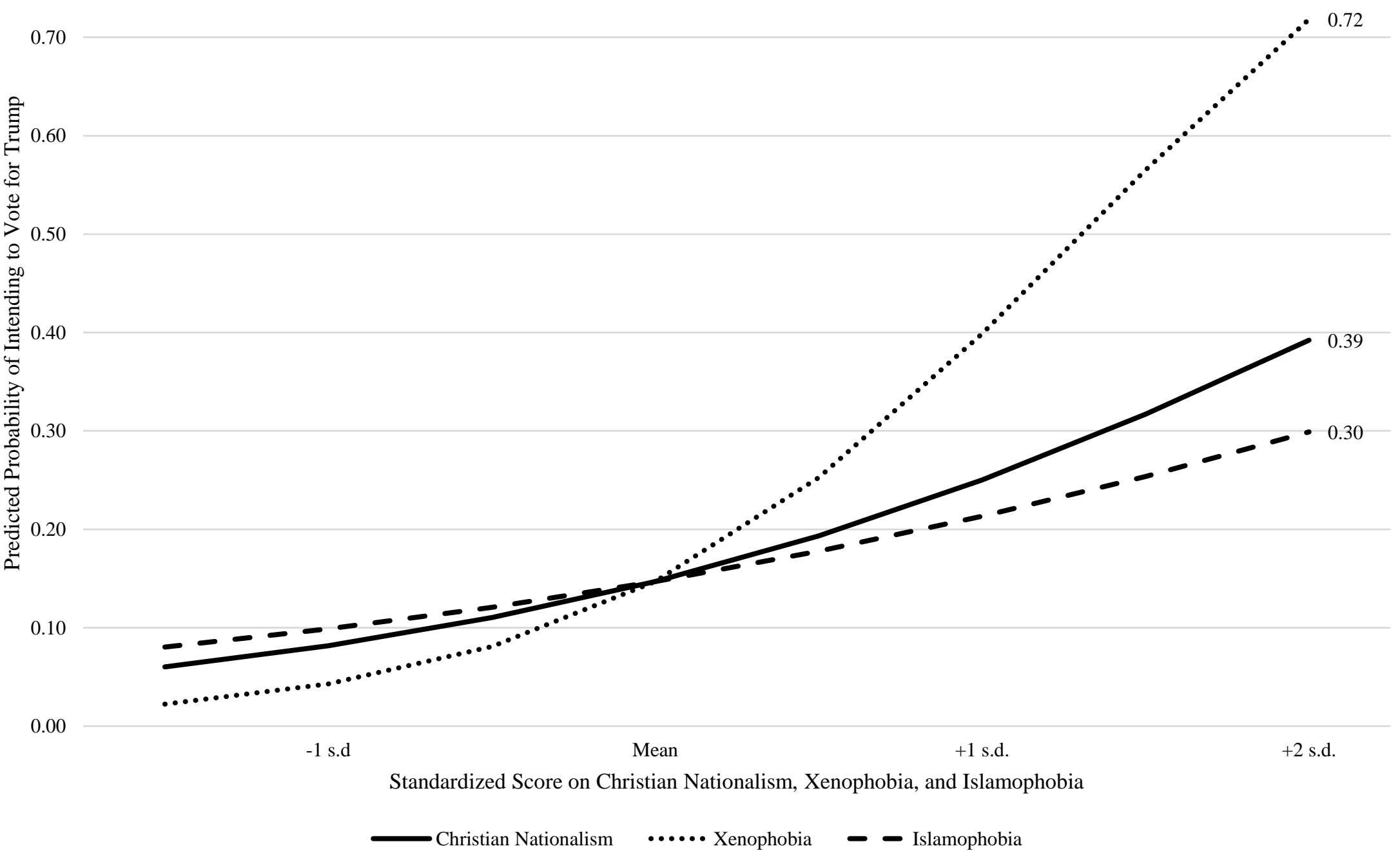


FIGURE 2. Multiple Mediation PROCESS Model with Direct and Indirect Effects of Christian Nationalism on Voting for Trump (Unstandardized Coefficients)

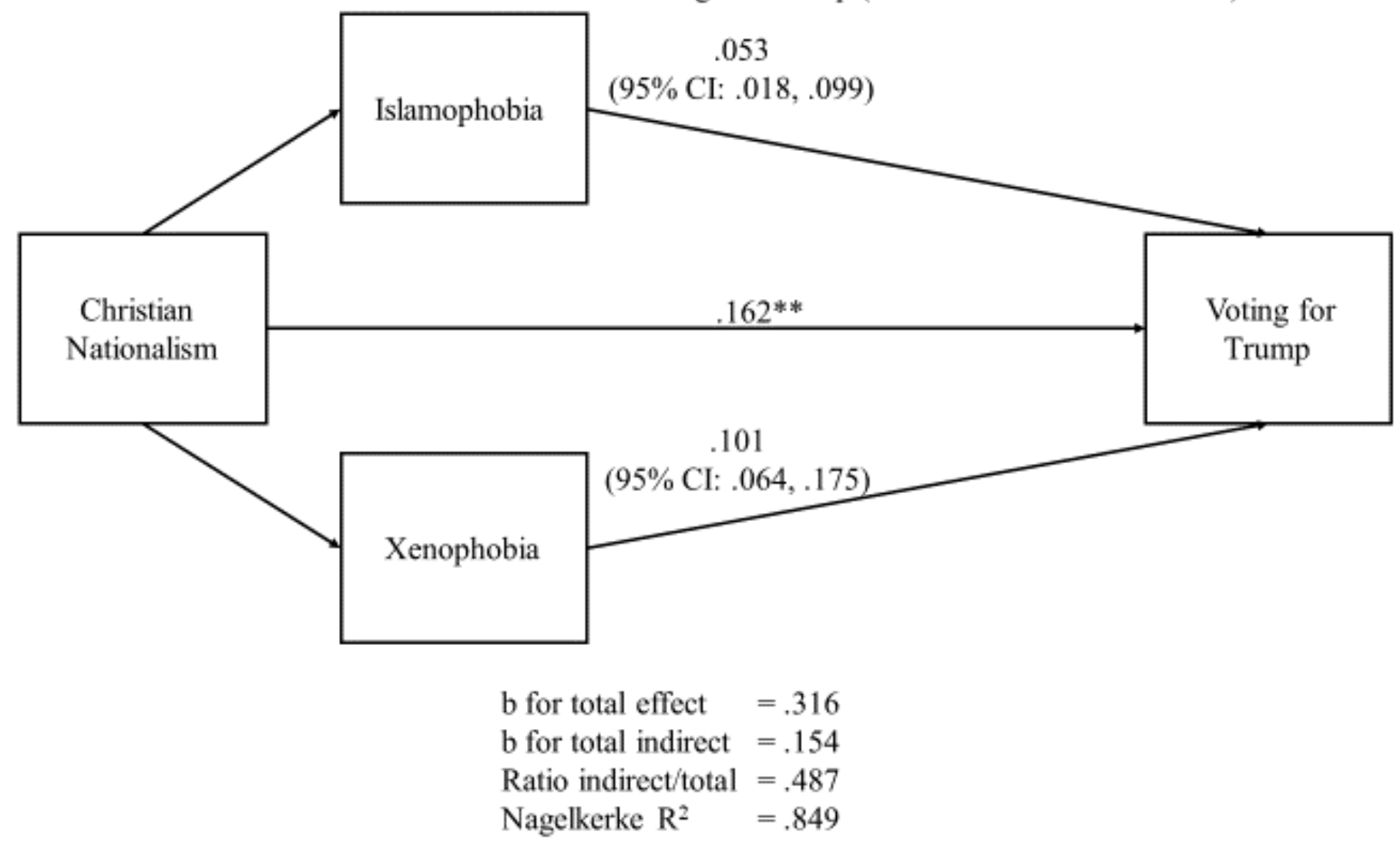

Note: Model includes all control variables shown in Table 3. 
TABLE A1. Descriptive Statistics for Variables Used

\begin{tabular}{|c|c|c|c|c|c|}
\hline Variables & Min & Max & Mean & Std. Dev. & $\mathbf{r}$ \\
\hline Vote for Trump & 0 & 1 & .37 & .48 & --- \\
\hline Christian nationalism & 5 & 20 & 11.71 & 3.92 & $.558 * * *$ \\
\hline \multicolumn{6}{|l|}{ Fears of "outsiders" } \\
\hline Xenophobia & 7 & 28 & 14.82 & 5.83 & $.709 * * *$ \\
\hline Islamophobia & 5 & 20 & 10.89 & 4.30 & $.641 * * *$ \\
\hline \multicolumn{6}{|l|}{ Fear of diversity } \\
\hline Race fear & 0 & 1 & .22 & .42 & $.361 * * *$ \\
\hline \multicolumn{6}{|l|}{ Sociodemographics } \\
\hline Gender & 0 & 1 & .49 & .50 & $.071^{*}$ \\
\hline Employed & 0 & 1 & .50 & .50 & -.048 \\
\hline Income & 1 & 9 & 5.06 & 2.61 & .021 \\
\hline Financial fears & 3 & 12 & 6.88 & 2.68 & $-.202 * * *$ \\
\hline Education & 1 & 8 & 4.71 & 1.77 & $-.204 * * *$ \\
\hline Married & 0 & 1 & .50 & .50 & $.208 * * *$ \\
\hline South & 0 & 1 & .35 & .48 & $.095 * *$ \\
\hline Northeast & 0 & 1 & .19 & .39 & $-.076^{*}$ \\
\hline Midwest & 0 & 1 & .20 & .40 & .002 \\
\hline West & 0 & 1 & .25 & .43 & -.038 \\
\hline White & 0 & 1 & .73 & .45 & $.336^{* * * *}$ \\
\hline Black & 0 & 1 & .12 & .32 & $-.254 * * *$ \\
\hline Hispanic & 0 & 1 & .15 & .36 & $-.182 * * *$ \\
\hline Asian & 0 & 1 & .04 & .20 & $-.090 * *$ \\
\hline Other or mixed race & 0 & 1 & .03 & .18 & .027 \\
\hline Age & 18 & 99 & 49.66 & 18.89 & $.242 * * *$ \\
\hline Metro & 0 & 5 & 2.46 & 1.52 & $.140 * * *$ \\
\hline \multicolumn{6}{|l|}{ Politics } \\
\hline Political views & 1 & 7 & 3.93 & 1.67 & $-.649 * * *$ \\
\hline Party identity & 1 & 7 & 4.20 & 1.82 & $-.703 * * *$ \\
\hline \multicolumn{6}{|l|}{ Religion } \\
\hline Service attendance & 1 & 9 & 3.89 & 2.63 & $.149 * * *$ \\
\hline Conservative Protestant & 0 & 1 & .08 & .27 & $.263^{* * *}$ \\
\hline Mod/liberal Protestant & 0 & 1 & .23 & .42 & $.102 * * *$ \\
\hline Catholic & 0 & 1 & .22 & .41 & .004 \\
\hline Jewish & 0 & 1 & .02 & .15 & $-.064 *$ \\
\hline Mormon & 0 & 1 & .03 & .16 & -.024 \\
\hline Other religions & 0 & 1 & .15 & .36 & -.025 \\
\hline No religion & 0 & 1 & .31 & .46 & $-.179 * * *$ \\
\hline
\end{tabular}

Source: 2019 Chapman Survey of American Fears

Note: Descriptives after listwise deletion of missing data $(n=1103)$. 
TABLE A2. Frequencies for High Levels of Christian Nationalism, Islamophobia, and Xenophobia

\begin{tabular}{lc}
\hline Category & Percentage of Respondents \\
\hline Christian nationalist & 46.1 \\
Islamophobic & 35.6 \\
Xenophobic & 25.0 \\
\hline Not in any of the three categories & 41.6 \\
Christian nationalist only & 16.6 \\
Islamophobic only & 7.3 \\
Xenophobic only & 1.7 \\
Christian nationalist + Islamophobic & 9.5 \\
Christian nationalist + Xenophobic & 4.5 \\
Islamophobic + Xenophobic & 3.5 \\
In all three categories & 15.3 \\
\hline
\end{tabular}

Source: 2019 Chapman Survey of American Fears

Note: Thresholds are agreeing to 3 out of 5 of the items on the Christian nationalism and Islamophobia indices and 5 out of 7 items of the xenophobia index. 
TABLE A3. Multinomial Logistic Regression Model Predicting Intention to Vote for Trump

\begin{tabular}{|c|c|c|}
\hline & Trump v. Democrat & Trump v. Third Party \\
\hline Christian nationalism & $-.800^{* *}$ & $-.523^{*}$ \\
\hline \multicolumn{3}{|l|}{ Fear of "outsiders" } \\
\hline Xenophobia & $-1.594 * * *$ & $-.903 * *$ \\
\hline Islamophobia & $-.753 * *$ & $-.641 *$ \\
\hline \multicolumn{3}{|l|}{ Fear of diversity } \\
\hline Race fear & .070 & -.074 \\
\hline \multicolumn{3}{|l|}{ Sociodemographics } \\
\hline Black $^{b}$ & $.790 * *$ & $.590^{*}$ \\
\hline Hispanic $^{b}$ & $.376^{*}$ & $.330^{\dagger}$ \\
\hline Asian $^{\mathrm{b}}$ & 168 & .061 \\
\hline Other or mixed race ${ }^{b}$ & .016 & -.048 \\
\hline \multicolumn{3}{|l|}{ Politics } \\
\hline Political views & $.912^{* *}$ & $.618^{*}$ \\
\hline Political identity & $2.985 * * *$ & $.798 * *$ \\
\hline \multicolumn{3}{|l|}{ Religion } \\
\hline Religious service attendance & -.080 & -.105 \\
\hline Moderate or liberal Protestant ${ }^{\mathrm{c}}$ & .046 & .058 \\
\hline Catholic $^{\mathrm{c}}$ & -.079 & .049 \\
\hline Jewish $^{\mathrm{c}}$ & .055 & .094 \\
\hline Mormon $^{c}$ & .197 & $.275^{*}$ \\
\hline Other religions $^{\mathrm{c}}$ & .132 & .095 \\
\hline No religion $^{c}$ & .066 & .451 \\
\hline \multicolumn{3}{|l|}{ Model stats } \\
\hline $\mathrm{N}$ & 1007 & 519 \\
\hline Constant & 1.283 & 0.282 \\
\hline$-2 \log$ likelihood & 717.571 & \\
\hline Nagelkerke $\mathrm{R}^{2}$ & .825 & \\
\hline
\end{tabular}

Source: 2019 Chapman Survey of American Fears

$\dagger \mathrm{p}<.1 ; * \mathrm{p}<.05 ; * * \mathrm{p}<.01 ; * * * \mathrm{p}<.001$

$\mathrm{b}$ : White is reference

c: Conservative Protestant. is reference

Note: Model includes controls for gender, employment, income, financial fears, education, marital status, region of the country, age, and metro location. 
FIGURE A1. Multiple Mediation PROCESS Model with Direct and Indirect Effects of Fear of Whites Being a Minority on Voting for Trump (Unstandardized Coefficients)

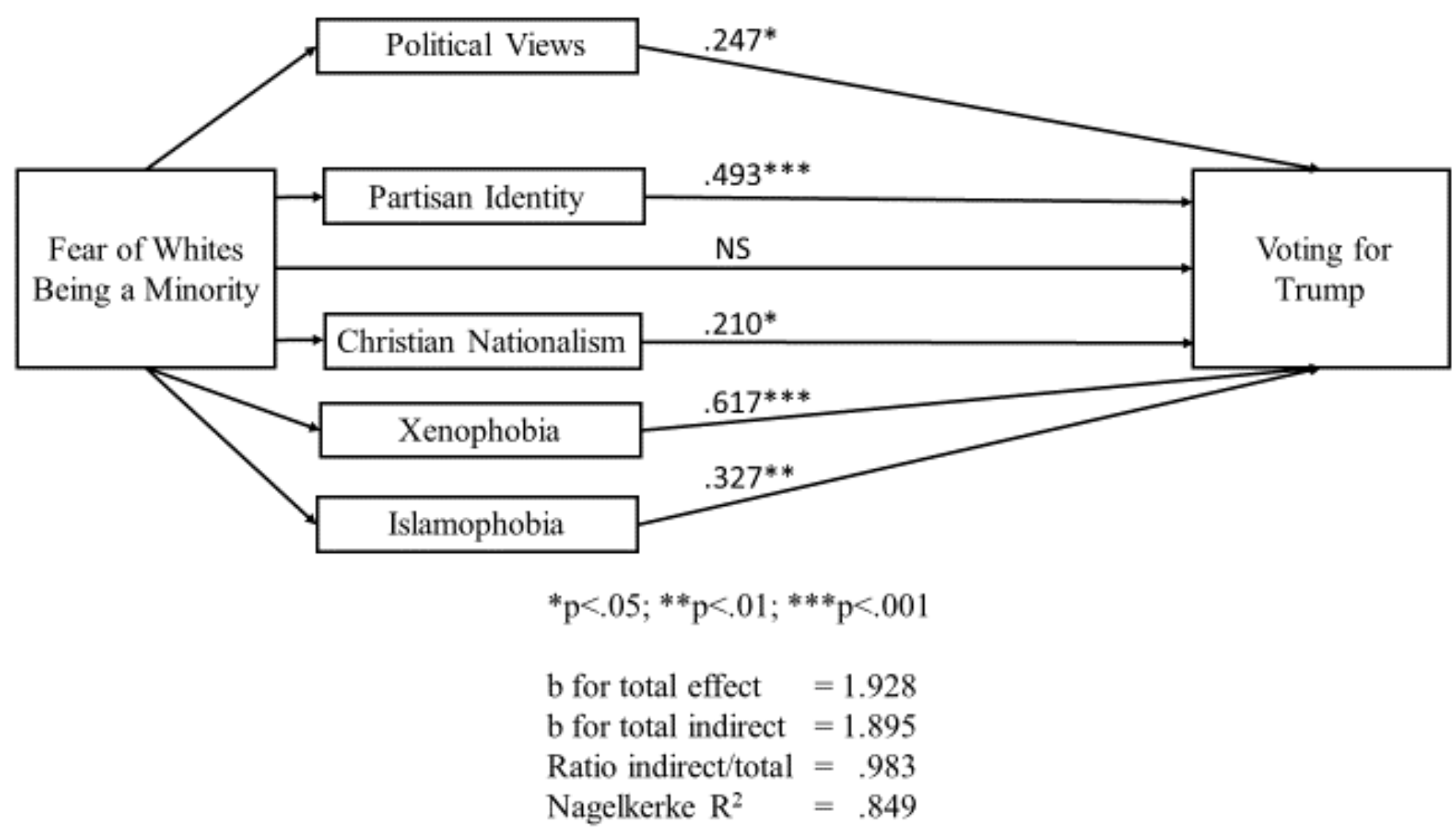

Note: Model includes all controls shown in Table 3. 
TABLE A4. Binary Logistic Regression Model Predicting Intention to Vote for Trump with Interactions for Racial Identification and Christian Nationalism

\begin{tabular}{|c|c|}
\hline Variable & $\mathbf{b}$ \\
\hline Christian Nationalism & $.158^{*}$ \\
\hline \multicolumn{2}{|l|}{ Fear of "outsiders" } \\
\hline Xenophobia & $1.527 * * *$ \\
\hline Islamophobia & $.573 * *$ \\
\hline \multicolumn{2}{|l|}{ Fear of diversity } \\
\hline Race fear & -.249 \\
\hline \multicolumn{2}{|l|}{ Sociodemographics } \\
\hline Black $^{b}$ & $-21.020 * *$ \\
\hline Hispanic $^{b}$ & $3.291 *$ \\
\hline $\operatorname{Asian}^{\mathrm{b}}$ & -.266 \\
\hline Other or mixed race $\mathrm{b}^{\mathrm{b}}$ & $-5.685^{\dagger}$ \\
\hline \multicolumn{2}{|l|}{ Politics } \\
\hline Political views & $-.692 * *$ \\
\hline Party identity & $-1.923 * * *$ \\
\hline \multicolumn{2}{|l|}{ Religion } \\
\hline Service attendance & -.108 \\
\hline Moderate or liberal Protestant ${ }^{c}$ & -.094 \\
\hline Catholic $^{\mathrm{c}}$ & -.147 \\
\hline Jewish $^{\mathrm{c}}$ & .000 \\
\hline Mormons ${ }^{c}$ & $-.227^{\dagger}$ \\
\hline Other religions $^{\mathrm{c}}$ & .036 \\
\hline No religion ${ }^{c}$ & -.336 \\
\hline \multicolumn{2}{|l|}{ Interactions } \\
\hline Black*Christian nationalism & $1.143 * *$ \\
\hline Hispanic*Christian nationalism & $-.378 * *$ \\
\hline Asian*Christian nationalism & -.118 \\
\hline Other races*Christian nationalism & $.480^{\dagger}$ \\
\hline \multicolumn{2}{|l|}{ Model stats } \\
\hline $\mathrm{N}$ & 1102 \\
\hline Constant & -3.162 \\
\hline$-2 \log$ likelihood & 379.065 \\
\hline Nagelkerke $\mathrm{R}^{2}$ & .840 \\
\hline
\end{tabular}

Source: 2019 Chapman Survey of American Fears

$\dagger \mathrm{p}<.1 ; * \mathrm{p}<.05 ; * * \mathrm{p}<.01 ; * * * \mathrm{p}<.001$

$\mathrm{b}$ : White is reference

c: Conservative Protestant is reference

Note: Model includes controls for gender, employment, income, financial fears, education, marital status, region of the country, age, and metro location 
41

FIGURE A2. Predicted Probability of Intending to Vote for Trump by Race/Ethnicity and Christian Nationalism




FIGURE A3. Moderated Mediation PROCESS Model with Direct and Indirect Effects of Christian Nationalism on Voting for Trump, Moderated by Survey Year (Unstandardized Coefficients)

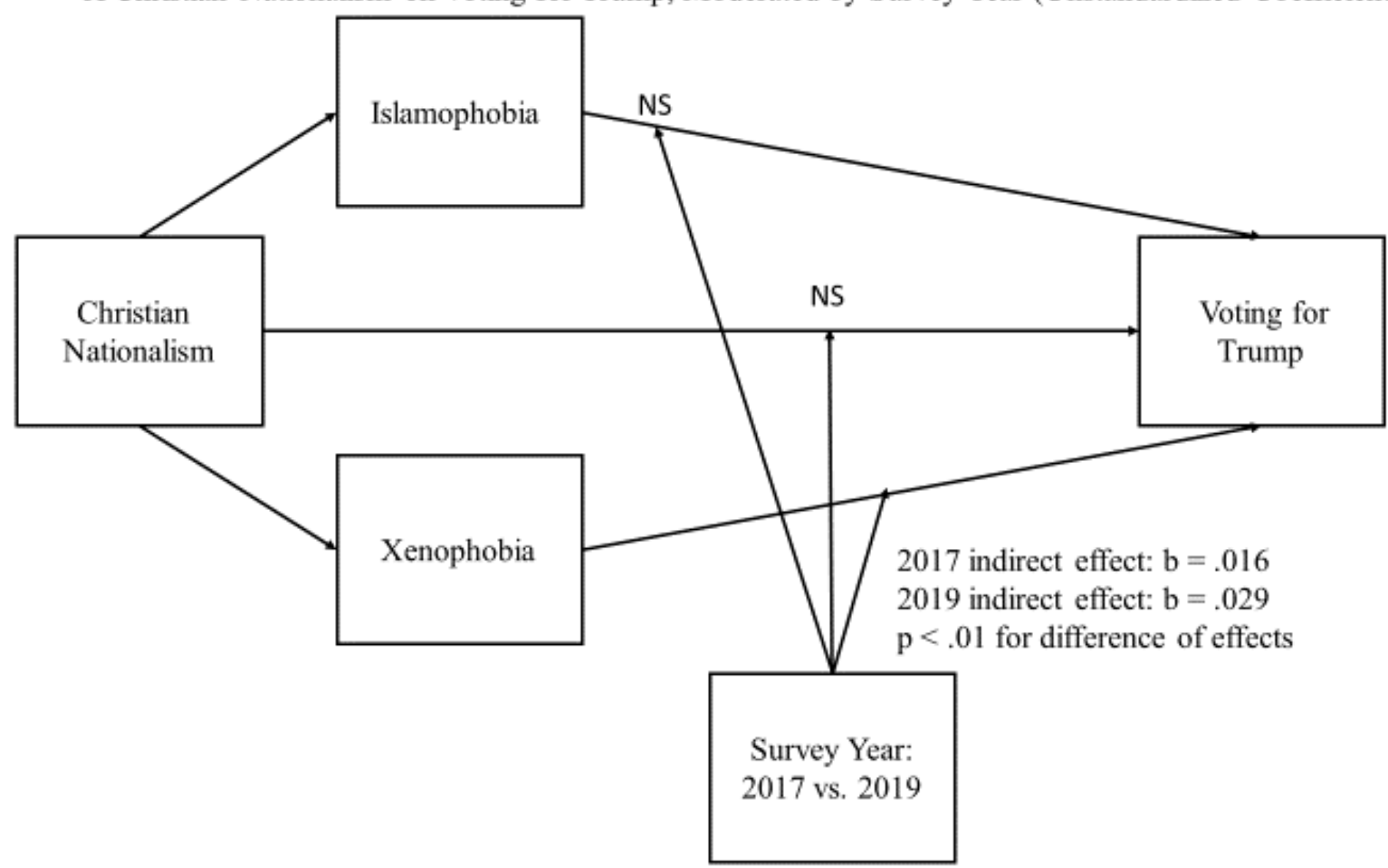

Note: Model controls for political views, partisan identification, financial dissatisfaction, race, gender, employment, income, education, marital status, religious service attendance, and Bible views. Xenophobia and Islamophobia measurement comparisons. Measurement for Islamophobia: "Refugees from the Middle East pose a terrorist threat to the United States" and "Muslims hold values that are morally inferior to the values of people like me" (2017 BRS); "Muslims are more likely to engage in terrorist activity than non-Muslims" and "Muslim values are at odds with American values and way of life" (2019 CSAF).

Measurement for xenophobia: "Illegal immigrants from Mexico are mostly dangerous criminals" (2017 BRS) and "Immigrants are more likely to commit crime than U.S. citizens" (2019 CSAF). 